\title{
27 MAYIS 1960 ASKERÎ DARBESİ SONRASI ALYANS KAMPANYASI
}

\author{
İbrahim İNCİ** Kübra ASLAN ${ }^{\star \star \star *}$
}

\begin{abstract}
$\ddot{\mathbf{O z}}$
Darbe öncesi ekonomik sorunlar sürekli kamuoyunun gündeminde yer almış ve darbenin nedenleri arasında gösterilmiştir. 27 Mayıs 1960 Askerî Darbesi sonrası yönetimde olan Millî Birlik Komitesi tarafından sabık hükümetin bıraktı̆̆ı borçlar ve Hazine'nin durumu sürekli olarak dile getirilmekteydi. Bu durumu çözmek adına bundan sonra bir kampanyalar silsilesi başlayacaktı. Hazine'ye gelir sağlamak veya devlete destek olmak adına yapılan kampanyalardan ilki "Alyans Kampanyası" olacaktı. 1. Zırhlı Tugay tarafından Hazine'deki altın stokunu artırmak için başlatılan bağış kampanyası halk tarafindan yoğun ilgi ile karşılandı. Kampanyaya çoğunlukla alyans olmak üzere birçok muhtelif bağış yapıldı. Dönemin gazeteleri, radyosu ve gündeminde yer alan bu kampanya, literatür taramaları sonucunda ayrıntılı olarak tartışılmayan bir konu olarak belirlenmiştir. Darbe sonrası Millî Birlik Komitesi dönemindeki sürecin bir kısmının açıklanmasında Alyans Kampanyası büyük önem arz etmektedir. Bu çalışmayla elde edilen bilgiler ışığında literatürdeki eksikliği gidermek amaçlanmıştır.
\end{abstract}

Anahtar Kelimeler: 27 Mayıs 1960 Askerî Darbesi, Bağış Kampanyası, Teberru, Hazine, Hatıra Halkalar.

\section{Abstract \\ Wedding Ring Campaign After May 27, 1960 Coup}

Economic problems before the coup were constantly on the agenda of the public and were seen among the causes of the coup.The National Unity Committee, which was in charge of the post-27 May 1960 Coup, was constantly talking about the debts and the state of the treasury left by the former government. To solve this situation, a series of campaigns would start from now on. The first campaign to provide income to the treasury or to support the state would be the "Wedding Ring Campaign". The donation campaign launched by the 1st Armored Brigade to increase the

\footnotetext{
* Manisa Celal Bayar Üniversitesi’nin Bilimsel Araştırma Projeleri Koordinatörlüğü tarafından, Kübra ASLAN'ın tezine ilişkin 2018-217 nolu proje kapsamında yapılan araştırmalar sonucunda bu çalışmada kullanılan kaynaklara ulaşılmıştır. Projede bu konu temel olarak ele alınacaktır. Konunun detaylı olarak araştırılması bu makale ile yapılmıştır. Desteklerinden dolayı Manisa Celal Bayar Üniversitesi’nin Bilimsel Araştırma Projeleri Koordinatörlüğü’ne teşekkürlerimizi sunarız.

** Doç. Dr. Manisa Celal Bayar Üniversitesi, Fen-Edebiyat Fakültesi, Tarih Bölümü, Manisa. E-posta: ibrhminci@hotmail.com. ORCID: 0000-0002-1357-6549

*** Manisa Celal Bayar Üniversitesi Sosyal Bilimler Enstitüsü Yüksek Lisans Öğrencisi. E-posta: kubra_aslan_1995@hotmail.com. ORCID: 0000-0003-2600-5945

(Makale Gönderim Tarihi: 01.09.2020 - Makale Kabul Tarihi: 23.04.2021)
} 


\section{İbrahim INCİ- Kübra ASLAN}

gold stock in the treasury received intense interest from the public.Various donations were made to the campaign, mostly including wedding rings. This campaign, which was frequently on newspapers of the period, radio and on the agenda of was determined as a subject that was not discussed in detail as a result of literature reviews. The Wedding Ring Campaign is of great importance in explaining some of the process during the post-coup National Unity Committee. In the light of the information obtained with this study, it is aimed to eliminate the deficiency in the literature.

KeyWords: The Coup Of May 27, 1960 Donation Campaign, Donation, Treasury, Commemorative Rings.

\section{Giriş}

Demokrat Parti iktidarının 1954-1960 dönemi ilk dönemine oranla ciddi ekonomik sorunların yaşandığı bir dönemdi. Bu dönem giderek artan diş ticaret açığı, dış borçlar, işsizlik, alım gücünün düşmesi ve 2. Dünya Savaşı zamanında biriktirilen altın, döviz rezervlerinin tükenmesi gibi sorunları doğurdu. Ekonomik büyümenin gerilemesiyle ilk yıllardaki olumlu hava yerini büyük bir yokluğa, iktisadi ve mali bunalıma bıraktı. ${ }^{1}$ D.P. iktidarının ekonomi politikası pahalılık, yokluk, kıtlık açısından muhalefet tarafından eleştiriliyor ve durum kötüleştikçe bu eleştiriler giderek artıyordu. ${ }^{2}$ Tüm bu ekonomik problemlerin yanında yaşanan siyasi krizler 27 Mayıs Askerî Darbesi ile sonuçlanmıştı. ${ }^{3}$ Darbe sonrası da dönemin Ticaret Bakanı Dr. Cihat İren, D.P.'nin ekonomi politikasını yanlış ve düzensiz olarak nitelendirip, altın stoklarının israf edildiğini söylemekteydi. ${ }^{4} \mathrm{Bu}$ eleştirilerde yer alan altın stokunun azalması problemi Alyans Kampanyası'nı ortaya çıkarmıştı. Kampanya için birçok farklı ifade kullanılmıştır. Bu makalede ise çıkış noktasının ve kampanyada en çok bağışlanan eşyanın "alyans" olmasından dolayı "Alyans Kampanyası" ifadesi kullanılacaktır.

27 Mayıs sonrası Hazine’ye gelir sağlamak amaçlı başlatılan kampanyalar silsilesinin ilki Alyans Kampanyası'dır. Alyans Kampanyası 1960 sonrası ekonomik durumu yansıtması açısından büyük bir önem taşımaktadır. Ondan önce başka bir amaçla 28 Mayıs 1960'da, darbeden hemen bir gün sonra "Hürriyet Anıtı" adı altında Akşam gazetesi tarafından bir kampanya başlatılmıştır. Öğrenci olaylarında ölenler için üniversite bahçesinde bir anıt kurulmasını öneren bu kampanya ${ }^{5}$ halk tarafından büyük ilgi görmüş̧ür. Nakit yardımların yanında alyanslarını da bağışlayan vatandaşlar olmuş ve her bağış yapan vatandaşın ismi Akşam gazetesinin sayfalarında yer almıştır. ${ }^{6} 2$ Haziran 1960'da sona eren bu kampanyadan ${ }^{7}$ k1sa bir süre sonra Alyans Kampanyas1 başlamıştır. Hürriyet Anıtı kampanyasının halk tarafından büyük ilgi görmesi akıllara başka bir kampanyanın başlatılması fikrini getirmiş ve bu durum Alyans Kampanyası'nın başlatılmasında etkili olmuştur denilebilir.

${ }^{1}$ Yücel 2007, s. 202,203,205,221.

${ }^{2}$ Demir 2018, s. 443.

${ }^{3}$ Tok 2017, s. 46.

${ }^{4}$ Ulus, 11 Haziran 1960, s. 3.

${ }^{5}$ Akşam, 28 Mayıs 1960, s.1.

${ }^{6}$ Akşam, 29-30 Mayıs 1960, s. 1.

${ }^{7}$ Akşam, 2 Haziran 1960, s.1. 


\section{Alyans Kampanyası}

“Hazine'ye yardım, paranın değerini arttırma, teberru, alyans bağışlama kampanyası" gibi farklı ifadelerle adlandırılan "Alyans Kampanyası" kimin tarafindan başlatıldığı tam olarak bilinmese de ${ }^{8}$ ilk defa 8 Haziran 1960 tarihinde 1. Zırhlı Tugay mensupları ve eşlerinin alyans ve diğer ziynet eşyalarını bağışlama girişimi ile başlamıştır. Daha sonra diğer ordu mensupları ve tüm vatandaşlar arasında yoğun bir ilgi görmüştür. ${ }^{9}$

Kampanyanın amacı "sabık idarenin mali bünyemizde bırakmış olduğu derin boşlukların kapatılması ve Devlet Hazinesi’ndeki altın stokunun takviyesi" ${ }^{10}$ olarak bildirilmiştir. Bunun yanında Hazine'yi güç durumdan kurtarmak, Türk parasının değerini artırmak ${ }^{11}$ gibi aynı amacı anlatan değişik ifadeler de sık sık kampanyanın açıklamalarında yer alacaktır. Temel olarak bakıldığında ise kampanyanın amacı “ekonomik krizi hafifletmek, Hazine'nin ödeme sıkıntısını geçici de olsa gidermek” idi. ${ }^{12}$

Kampanyanın getirisi hakkında ilgilerin yaptı̆̆ı tetkiklere göre: ülkenin yaklaşık 30 milyonluk nüfusunun üçte biri evli ve tüm evli vatandaşların alyans ve çeşitli ziynet eşyaları bulunmaktaydı. Yine ilgililerin ifadelerine göre bu vatandaşların sadece alyanslarını bağışlamaları bile Hazine'ye büyük bir altın stoku kazandıracak ${ }^{13}$ ve bu alyansların Hazine'ye getirisi toplam 15-20 ton altın olacak, diğer ziynet eşyaları ve nakit ile birlikte bu miktar 200 milyon lirayı aşacaktı. ${ }^{14} \mathrm{Bu}$ konuda ilgililerin verdiği veriler yaklaşı miktar olarak kabul edilebilir.

1960 yılı Türkiye'nin nüfusu 27.754.820 kişidir. Bu nüfusun \%73,53'ü yani 11.941.534 kişisi evlidir. ${ }^{15} \mathrm{Bu}$ sayı nüfusun üçte birinden fazladır. İlgililerin Alyans Kampanyası'na ne kadar bağışta bulunacağı dair tahmini açıklamaları, 1960 yılı evli nüfusun yaklaşık 12 milyon olduğu ve Hazine'nin durumu göz önüne alınınca Hazine'ye böyle yüksek bir getiri sağlayacak kampanyanın gelişigüzel başlatılmasından ziyade planlanarak başlatılmış olabileceği düşündürtmektedir.

Kampanya başladıktan hemen iki gün sonra Maliye Bakanlığı'nın tüm şubeleri makbuz karşılığında bu bağışları toplamaya başlamıştır. Tabii bu süreçte bazı kurum ve vatandaşlar mücevherlerini, Devlet Hazinesi'ne intikal ettirmek üzere Hazine Umum Müdürlüğü'ne de teslim etmiştir. (EK1)

Maliye Bakanı Ekrem Alican ise 9 Haziran'da kampanyaya dair vatandaşlara şükranlarını sunup kampanya hakkında şu sözleri dile getirmiştir: "Maliye Bakanlığı, vatandaşın hizmetindedir. Vilayet ve kazalarda kurulan heyetlerle birlikte bağışlar makbuz dahilinde, herhangi bir ihmale firsat vermeksizin teslim alınacaktır. $\mathrm{Bu}$ doğrultuda gerekli emirler bakanlığa verilmiştir. Aynı zamanda bu sürecin nasıl işleyeceğine dair yarın (10 Haziran 1960) radyolar ve resmî makamlardan gerekli

\footnotetext{
${ }^{8}$ Weiker 1967, s. 178.

${ }^{9}$ Milliyet, 9 Haziran 1960, s. 1; Akşam, 9 Haziran 1960, s. 1.

${ }^{10}$ Akşam, 9 Haziran 1960, s. 1.

11 Akşam, 16 Haziran 1960, s. 1.

12 Alkan 2016, s. 124.

13 Akşam, 10 Haziran 1960, s. 5.

14 Akşam, 12 Haziran 1960, s. 4.

15 TÜİK 2010, s. 8, 16, 17.
} 
açıklamalar yapılacaktır." ${ }^{16}$ Ertesi gün gazetelerde yer alan açıklamalara göre Maliye Bakanlığı'nın belirlediği esaslar ise şu şekildedir: edilecektir.

"a) Nakit, platin, altın ve gümüşten oluşan ziynet eşyaları bağış olarak kabul

b) Bağışlar, 'vilayetlerde muhasebe müdürü, kazalarda mal müdürü, askeri ve mülki muhasipliklerde mesul muhasip ile veznedarlar ve mahalli en büyük mülkiye amirinin veya birlik kumandanın tayin edeceği bir şahıstan müteşekkil üç kişilik heyete makbuz mukabilinde teslim olunacaktır." 17

Bu açıklama doğrultusunda İstanbul'da alyanslar için İstanbul Deftarlığı'ndaki Millî Emlak Müdürlügü̈'nde Kurmay Binbaşı İsmet Akova başkanlığında "Bağış Kabul ve Tesellüm Heyeti" adı verilen bir komisyon kurulmuştur. (EK 2-3) Komisyonda aynı zamanda Sebahattin Tönük ile Defterdar Muavini Gazi Külür ve bir darphane kimyageri bulunmaktadır. Yüzükleri vasıf, ayar ve gramlarına göre tespit eden bu komisyon, bağışları zabitla teslim almaktadır. ${ }^{18}$

Nakit bağışlar ya altın yaptırılarak ya da maliye muhasebesinden ayrı bir makbuz kestirilerek kabul edilmektedir. ${ }^{19}$ Daha sonra artan bağışlar nedeniyle bu komisyonun çalıştığı oda ve memur sayısı arttırılmıştır. ${ }^{20}$ Bağış̧ların toplandığı başka bir yer ise Akşam gazetesi olmuştur. Gazete mensupları kendilerine getirilen bağışları makbuz karşıllğı Millî Emlak Müdürlüğü'ne teslim etmiştir. ${ }^{21} 17$ Haziran'dan sonra ise bağışların sadece deftardarlıklardaki Millî Emlak Müdürlükleri, kaymakamlıklar ve mal müdürlükleri tarafından kabul edileceği ve bunlar dışında başka kurumlara başvurulmaması gerektiği açıklanmıştı. ${ }^{22}$

16 Haziran 1960 tarihli tebliğ'de ise Millî Birlik Komitesi, Devlet Başkanı ve Başbakan Orgeneral Cemal Gürsel, kampanya ile ilgili halka teşekkürlerini sunmuş ve halkı karşılıksız bağışlardan ziyade çıkarılması planlanan Hürriyet İstikrazi adı verilen tahvillerine yöneltmiştir (EK 4) ${ }^{23}$.

\section{Bağısşlar}

Hürriyet Anıtı kampanyasında olduğu gibi bu kampanyada da ülkenin her yerinden yapılan bağışlar, bağış̧̧ııın adıyla birlikte pek çok gazetede yer almaktaydı. ${ }^{24}$

İzmir Askerî Valiliği'nin 16 numaralı tebliğinde de Merkez Bankası kasasına teslim edilecek miktarın her gün basın, radyo ile halka duyurulacağına yer

\footnotetext{
${ }^{16}$ Akşam, 10 Haziran 1960, s. 1, 5.

${ }^{17}$ Akşam, 11 Haziran 1960, s. 1, 3.

${ }_{18}$ Akşam, 11 Haziran 1960, s. 1, 3; Tercüman,12 Haziran 1960, Say1: 179, s. 5.

${ }^{19}$ Akşam, 12 Haziran 1960, s. 4.

${ }^{20}$ Akşam, 15 Haziran 1960, s. 3.

${ }^{21}$ Akşam, 13 Haziran 1960, s. 3. Milli Emlak Müdürlüğü’nün 3. kişilere açık bir arşivi yoktur. Bu anlamda bu kuruma ait veriler çalışmada bulunmamaktadır.

22 Akşam, 17 Haziran 1960, s. 3.

${ }^{23} 10550$ sayılı Resmî Gazete, s. 1720 .

${ }^{24}$ Akşam, 12 Haziran 1960, s. 1, 5; Ulus, 12 Haziran 1960 s. 1, 5; Tercuman, 15 Haziran 1960, s. 1,5 .
} 
verilmekteydi ${ }^{25}$. Bu uygulamanın amacı bağış miktarlarının halka açık olduğunu, kampanyanın istismar edilmediğinin görülmesinin yanında isimlerinin gazetelerde ve radyoda yer almasının bağışları arttıracağıydı denilebilir. Hatta zaman zaman bu anlamda gazetelerde bağış yapmak için gösterilen büyük fedakârlık öyküleri de yer almaktayd1. ${ }^{26}$

Kampanya Edirne'de ise Edirne Askerî Garnizonu tarafindan 19 numaralı tebliğle millî altın stoklarının yok edildiği ifade edilerek başlatılmıştı. Ancak Edirne'de Alyans Kampanyası'nın zorunluluk arz ettiği iddialarına karşı Edirne Valisi Sadri Sarptır bir tebliğ yayınlayarak, bu tarz haberlerin kasıtlı olarak çıkarıldığı, bağışların gönüllülük esasına dayandığı açıklamış ve bu tarz haberleri yayan kişilerin bildirilmesi istemiştir. ${ }^{27}$

Erdem Yavuz'un da çalışmasında bahsettiği gibi 1960 darbesi sonrası dönem algı yönetimi, toplumsal algı oluşturmada öne çıkmaktaydı. Alyans Kampanyası'nda da gazete ve radyo tam bu anlamıyla kullanılmıştı. Bundan sonraki tüm süreçte basının "aşırı iyimser" tavrı dikkat çekmekteydi. "Darbe" kelimesi yerine sürekli "ihtilal" ve "inkılap" kelimeleri kullanılmış ve ordunun aleyhine hiçbir habere yer verilmemişti. Daha önce ifade edilen "Hürriyet Anıtı Kampanyası" da bunun örneklerindendi. Amaç 27 Mayıs'ın halka benimsetilmesi idi. Tabii ki bu sadece Hürriyet Anıtı Kampanyası veya Alyans Kampanyası ile sınırlı kalmamış, ${ }^{28}$ Hatıra Pulları,ilk gün zarfları, hatıra parası, sigara ve plaklar da aynı amaçla kullanılmıştır. Bunlar hem olumlu bir algı oluşturma hem de Alyans Kampanyası gibi gelir sağlama amaçlı kullanılmıştır. Daha sonra bahsedilecek olan tahviller bunun bir örneğidir. ${ }^{29}$

$\mathrm{Bu}$ icraatlerde ekonomik etkenler kadar psikolojik etkenlerde önemli rol oynamıştı. Alyans Kampanyası bu anlamda, altın stoklarında önemli bir artışa neden olmamasa da DP'nin bıraktığı mali buhranın dramatikleştirilmesi adına büyük bir psikolojik etki yaratmıştılması için kullanılmıştı. Gürsel bu kampanyanın iktisadi yararının sınırlı olacağını farkettiği için halkı tahvillere yönlendirmiştir. ${ }^{30}$

Kampanyada ağırlıklı olarak alyans bağışı yapılsa da para ve muhtelif ziynet eşyalarının yanında altın diş, işçilerin mesaileri, fabrika sahiplerinin makinelerinin geliri $^{31}$, nişan töreninde nişanlıların ve davetlilerin alyansları, şehir sinemalarının bir günlük hasılat ${ }^{32}$, hamam hasılatı, Gaziantep Belediye Başkanının Adnan Menderes için hazırlattığı 110 gramlık som altından olan şehrin anahtarı, dükkan, safkan at, boğa ${ }^{33}$,

\footnotetext{
${ }^{25}$ Demokrat İzmir, 11 Haziran 1960, Y11: 14, Say1: 4708, s. 1, 2.

${ }^{26}$ Akşam, 12 Haziran 1960, s.3, Bir Ay Kuru Ekmek Yiyeceğim Hazineye Yardım Edeceğim; Akşam, 12 Haziran 1960, s. 4, Vatandaşlar Altın Bağışı İçin Yarışıyorlar.

${ }^{27}$ Tuna 2017, s.72,75.

${ }^{28}$ Yavuz 2017, s. 97, 100,102,

${ }^{29}$ Alkan 2016, s. 124, 127.

${ }^{30}$ Weiker 1967, s.178, 179 .

${ }^{31}$ Akşam, 12 Haziran 1960, s. 3,4.

${ }^{32}$ Akşam, 13 Haziran 1960, s. 1.

${ }^{33}$ Akşam, 15 Haziran 1960, s. 3.
} 
şamdan ${ }^{34}$, kahve hasılatı, otobüs hasılatı, Menderes'in bir milli maçtan sonra idareci ve futbolculara verdiği kendi imzasını taşıyan kol saati ${ }^{35}$, bir bebeğin maşallahı ${ }^{36}$ gibi pek çok farklı bağış görülmüş̧ür. (EK 5)

Bağışların boyutuna dair Nâzım Hikmet'in bir hikayesine de burada yer vermek doğru olacaktır.

27 Mayıs'tan sonraki aylarda Moskova'daki bir edebiyat kongresi için bir Türk heyeti gelmişti. Kongreye giden Nâzım Hikmet Türkiye'den gelenlerin hiçbirinin parmağında alyans olmadığını görünce, "Hayrola artık Türkiye'mde alyans takılmıyor mu?" diye sordu. Kongreye gelen heyette bulunan Ömer Sami Çoşar ve Fahir Îz Türkiye'de hâzineye bir yardım kampanyası açıldığını ve alyanslarını bu kampanyaya bağışladıklarını ifade etmişlerdi. Nâzım Hikmet söylenenlerden sonra parmağındaki alyansı bağışlamaları için Fahir Îz'e uzattı. Fahir Bey gümrükten geçerken alyanssız geçtiklerini, dönerken bir alyansla dönemeyeceklerini söylediğinde Nâzım Hikmet elinde alyansı ile bir süre başını önüne eğdi ve durdu. Ekber Babayef'in anlattığ $1^{37} \mathrm{bu}$ hatıra ile yukarıda sadece alyans değil her çeşit bağışın yapıldığına dair kısım o dönemki bağış miktarını ve kampanyanın gördüğü ilginin boyutunu gözler önüne sermektedir.

Bağışlarda dikkat çeken başka bir unsur ise pek çok D.P.'li ismin de kampanyaya katılmasıdır. ${ }^{38}$ Bunun dışında kampanyaya yabancı vatandaşlardan da çeşitli katılımlar gerçekleşmiştir. Kore kafilesini götürecek olan Amerikalı denizci ve bir NATO personeli yüzüğünü ${ }^{39}$, Musevi cemaatinin dini lideri Haham Rafael Salon dini sembolü olan boynundaki som altından yapılmış kolyesini, yanında gelen refakatçiler de alyanslarını ${ }^{40}$ ve Rum-Ortodoks Patrik vekili Emiliyanos 10 bin lira ${ }^{41}$ bağışlamıştır. Bağışların yanı sıra İstanbul'da Ermeni Patriği Haçodaryan kiliselerine bir tamim gönderip, heyetler kurdurarak kampanyaya vatan hizmeti olarak desteklemelerini ${ }^{42}$, Patrik Athenagoras da Ortodoks vatandaşların kampanyayı katılmasını istemiştir. ${ }^{43}$ Aynı zamanda Ermeni okulları da ${ }^{44}$ kampanyaya destek olmuşlardır. (EK 6)

Diğer taraftan bu süreçte halk tarafından yapılan bağışların istismar edildiği ve köylülerin bütün altınlarına ve paralarına zorla el konulacağı şeklinde bazı konuşmalar yaşanmaktaydı. Bu o dönem İç İşleri Bakanlığı tarafından eski iktidar destekçilerinin propagandası olarak nitelendirilip yalanlanmıştır. ${ }^{45}$

\footnotetext{
${ }^{34}$ Akşam, 16 Haziran 1960, s. 1,3.

${ }^{35}$ Akşam, 17 Haziran 1960, s. 3.

${ }^{36}$ Akşam, 18 Haziran 1960, s. 1.

37 Soysal 1964, s. 9.

${ }^{38} \mathrm{http}$ ://www.cukurovaexpres.com/27-mayis-ve-mersin-6-makale,344.html, (E.T. 27.06.2020). Yazar bu isimleri "Lokmanoğlu, Tanrıverdi ve benzeri isimler" şeklinde vermiştir.

${ }^{39}$ Akşam, 15 Haziran 1960, s. 3.

${ }^{40}$ Akşam, 18 Haziran 1960, s. 1.

${ }^{41}$ Akşam, 19 Haziran 1960, s.1.

42 Akşam, 17 Haziran 1960, s. 3.

${ }^{43}$ Tercüman, 19 Haziran 1960, s. 1.

${ }^{44}$ Akşam, 26 Haziran 1960, s. 5.

${ }^{45}$ Akşam, 21 Haziran 1960, s. 5.
} 


\section{Hatıra Halkalar}

11 Haziran'da 1960'da Akşam gazetesi, “Hürriyet içinde kalkınma bütün milletçe benimsendi." başlıklı haberi ile Maliye Bakanlığı'na yapılan bu bağışlar karşılığında vatandaşlara sembolik bir yüzük verilmesinin teklif ediyordu. ${ }^{46} \mathrm{Bu}$ yüzüklerin kampanyaya katılımı arttıracağını ${ }^{47}$ ve alyanslarını bağışlayan vatandaşın piyasadan yeni alyans alarak amaçlananın aksine altın fiyatlarının yükseltilmesinin engellenebileceği düşünülmüştü. ${ }^{48}$ İzmir'de ise bu düşünce Maliye Bakanlığı'ndan ayrı olarak uygulamaya konulmuştu. İzmir'de 13 Haziran 1960 tarihinde başlayacak kampanyada bağış yapanlara İzmir Kuyumcular ve Sarraflar Derneği tarafından hazırlanan 27.05.1960 tarihli Millî Birlik rumuzlu bir gümüş alyans hediye edileceği duyurulmuştu. ${ }^{49} \mathrm{Bu}$ uygulamanın Maliye Bakanlığ $\breve{1}_{1}$ tarafından resmileştirilmesi ise 13 Haziran 1960'da yapılan açıklama ile oldu. Açıklamaya göre, alyanslarını bağışlayan vatandaşlara bağışları karşılığında hatıra halkalarının verilecektir. Bu halkaların hızlıca üretimi için darphanede gerekli tedbirler alınmış ve dağıtım içinde mal sandıklarıyla askeri ve mülki muhasiplikler belirlenmiştir. ${ }^{50} \mathrm{Bu}$ karardan önce bağış yapanlara ise yüzükleri makbuzlarla alabileceği bildirilmişti. ${ }^{51} \mathrm{Bu}$ yüzüklerin üzerinde ilk olarak karanfil, lale ve ay-yıldız gibi motiflerle birlikte 27.05.1960 tarihinin bulunmas1 gibi fikirler ortaya atılmıştır. ${ }^{52}$ Daha sonra kesin karar için model resimleri MBK'ya gönderilmiş ve 17 Haziran'da yüzüklerin hazırlığına başlanmıştır. ${ }^{53}$ Dağıtımın sürekli olması adına stok yapılmasına karar verilmiştir. ${ }^{54}$

\section{Kampanyanın Gidişatı}

Kampanya gün geçtikçe büyümekte, genişlemekte ve katılım her gün giderek artmaktayd1. ${ }^{55}$ Dönemin gazeteleri de "Vatandaşlar altın bağışı için yarışıyorlar. ${ }^{56}$ "Hazine'ye alyans yağmuru arttı. ${ }^{57}$ "Bağ 1 şlar çı̆̆ gibi büyüyor" ${ }^{58}$ şeklindeki haber başlıkları ile kampanyanın gidişatına yer vermektelerdi. İlginin giderek arttığ kampanyanın başlamasıyla birlikte halk bazında esnaflar arası bir "Ucuzluk Kampanyası" da başlamıştı. ${ }^{59} \mathrm{Bu}$ süreçte sürekli altın fiyatlarının düştüğü de sık sık dile getirilmekteydi ${ }^{60}$.

\footnotetext{
${ }^{46}$ Akşam, 11 Haziran 1960, s. 1,3.

${ }^{47}$ Akşam, 12 Haziran 1960, s.3.

${ }^{48}$ Akşam, 13 Haziran 1960, s.1.

${ }^{49}$ Demokrat İzmir, 11 Haziran 1960, Y11: 14, s.1,2.

${ }^{50}$ Akşam, 14 Haziran 1960, s. 1

${ }^{51}$ Akşam, 17 Haziran 1960, s. 3.

${ }^{52}$ Akşam, 15 Haziran 1960, s. 1.

${ }^{53}$ Akşam, 17 Haziran 1960, s. 1,3.

${ }^{54}$ Akşam, 29 Haziran 1960, s. 5.

${ }_{55}$ Akşam, 16 Haziran 1960, s.1.

${ }^{56}$ Akşam, 12 Haziran 1960, s. 4.

${ }^{57}$ Akşam, 13 Haziran 1960, s. 1.

58 Tercüman, 22 Haziran 1960, s. 1.

${ }^{59}$ Akşam, 12 Haziran 1960, s. 3.

${ }^{60}$ Tercüman, 11 Haziran 1960, s. 5.
} 
Tercüman gazetesinde yer alan altın fiyatının düştüğüne dair haber, Cumhuriyet alıınıı baz alınarak değerlendirildiğinde: Cumhuriyet altınının normal satış fiyatı 80 lira olmalıydı. 27 Mayıs'ta Cumhuriyet altını 112 lira, 11 Haziran'da 105, 13 Haziran'da ise 99 liraydı. Sarraflara göre de 90 liraya kadar inmeye devam edecekti. ${ }^{61}$ Ancak umulduğu gibi altın fiyatları düşmedi, artmaya devam ederek 30 Haziran'da 103-103.25 liraya yükseldi. Bundan sonraki dönemde de yaklaşık 100 ile 108 lira arası sürekli değişiklik gösterecekti. ${ }^{62}$ İstatistiki verilerde yer alan bilgiye göre de 1960 yılı Cumhuriyet altınının fiyatının ortalama değeri 108 liraydı. Normal kabul edilen 80 liraya ise en yakın değere 1956 yılında 84 lira ile ulaşılmıştır. ${ }^{63}$ Buradan anlaşılmaktaydı ki Alyans Kampanyası piyasada sadece geçici bir etki yaratmıştı.

Kampanya ilerledikçe ilgililerin yaptı̆̆ getiri tahminleri de değişmekteydi. Haberde yer alan bilgiye göre, 100 kişiden alınan alyanslar 1 kilo etmekte, kampanyaya 10 milyon kişinin katılımı sağlanırsa bu Hazine'ye 10 tonluk altın sağlanacak demekti. ${ }^{64}$ Tabii bu miktara diğer ziynet eşyaları ve nakit bağışlar eklenmemiş olsa da önceki tahminlerinin altında bir hesaptı.

Kampanyaya birçok alyans ve muhtelif ziynet eşyalarının yanında dikkat çeken büyük miktardaki bağışlar da olmuştu.Ticaret Borsası 1 milyon lira ${ }^{65}$ Vehbi Koç bu zamana kadar biriktirdiği tüm altın birikimini $(26 \mathrm{kilo})^{66}$, bir vatandaş ise 2 milyon lirasını bağışlamıştı. ${ }^{67}$

Gazetelerde yer alan miktara göre İstanbul'da toplam o güne kadar yapılan bağış, 2 milyon 46 bin 911 lira 37 kuruştur. Bunun 999 bin 257 lirası muhtelif ziynet eşyası, 1 milyon 108 bin 538 lira 46 kuruşu nakit, 29 bin 100 lirası da tahvildir. ${ }^{68} \mathrm{Bu}$ miktar 5 Temmuz'da ülke genelinde 10 milyon 828 lira $^{69}, 10$ Temmuz'da ise 12 milyon 50 bin 100 lira 95 kuruştu. Ve bunun 514 kilo 721 gramı altın ve kıymetli madendi. ${ }^{70}$ (EK 7)

Alyans Kampanyası devam ederken çıkarılan başka bir gelir sağlama aracı “Hürriyet İstikrazı Tahvilleri” idi. 15 Temmuz 1960'da tedavüle çıkarılan bu tahviller, Alyans Kampanyası'ndaki aynı amaçla Hazine'ye yatırımı kolaylaştırmak ve memleket maliyesine destek amacıyla çıkarılmıştı. ${ }^{71}$ Tahviller, yoğun bir ilgi ile karşılandı ve vatandaşlara bankalar ${ }^{72}$, askerî ve mülki saymanlıklar, mal sandıkları aracılığıyla ulaştırıldı. Vergisiz, sağlam bir gelir kaynağı olarak sunulan tahviller $\% 6$ faiz getirisi ile

\footnotetext{
${ }^{61}$ Tercüman, 14 Haziran 1960, s. 5.

${ }^{62}$ 27.05.1960-31.12.1961 tarihleri arasında Ekonomi Gazetesi'nde yer alan verilerin en düşük ve en yüksek değerine göre hesaplanmıştır.

${ }^{63}$ TÜIKK, 2010; 576.

${ }^{64}$ Akşam, 17 Haziran 1960, s. 3.

${ }^{65}$ Akşam, 15 Haziran 1960, s. 3.

${ }^{66}$ Akşam, 26 Haziran 1960, s. 1.

${ }^{67}$ Yeni Sabah, 14 Temmuz 1960, s. 1.

${ }^{68}$ Akşam, 26 Haziran 1960, s. 1, 5.

${ }^{69}$ Akşam, 5 Temmuz 1960, s. 1.

70 Tercüman, 10 Temmuz 1960, s. 1.

71 Tercüman, 15 Temmuz 1960, s. 5.

72 Tercüman, 16 Temmuz 1960, s. 1.
} 
satışa sunulmuştu. ${ }^{73}$ Bundan sonraki dönemde Alyans Kampanyası gündemde çok nadir yer alacaktı. Bunun yerine tahviller artık Hazine'ye gelir sağlayan farklı bir araç olarak Alyans Kampanyasında da olduğu gibi sık sık gazetelerde reklamı yapılacak ve vatandaşlar tahvil almaya sevk etmeye çalışılacaktı. (EK 8)

$\mathrm{Bu}$ esnada ise Alyans Kampanyası için hazırlanan yüzüklerin dağıtımına başlanmıştı. Vatandaşa dağıtım makbuzla mal müdürlükleri ve defterdarlıklardan yapılacaktı. ${ }^{74}$ Üzerinde defne dalı, 27.05.1960 tarihi olan ve nikelden yapılan bu yüzükler ${ }^{75}$ ilk olarak Genelkurmay Başkanlığında Hazine'ye yüzük bağışlamış olanlara verilmiştir. $^{76}$ (EK 9-10)

Kampanyadaki bağışlar için dikkat çeken başka bir husus da bu bağışlar ile ne yapılacağı olmuştur. İstanbul Belediyesi'ndeki özel mülklerin kamulaştırılması ve vatandaşa yapılacak ödemelerin de bu bağışlar kullanılarak yapılacağına dair söylentiler gündeme gelmiştir. Bu konuda Millî Birlik Komitesi Üyesi Mehmet Özgüneş, borçların bir kısmının tahvillerle ödendiğini ancak vatandaşın Hazine'ye hediye ettikleri yüzüklerle bu borçların ödenmemesi gerektiği şeklinde bir çıkışta bulunmuştur. ${ }^{77} \mathrm{Bu}$ Özgüneş’in bağışlara yönelik tek söz alışı olmamıştır. Özgüneş daha sonra dönemin Hariciye Bakanı'nın bindiği 1955 model Cadillac arabayı beğenmemesi ve yeni araba için teklifte bulunmasının üzerine "Halkımız bir taraftan parmağından yüzügüunü çıkarıp Hazine'ye verip, çıplak ayakla dolaşırken bu teklifin meclise gelmesine bile cüret edilemez." demiştir. ${ }^{78}$

Kampanya dönemi başka bir önemli mesele ise, Hazine'ye yurt dışından gelen ve gelecek olan yardımların vergiden muaf olması hakkında İktisat Komisyonu'na 4 Ekim 1960 'da sunulan tasarıyd1. ${ }^{79}$ Bir sonraki meclis toplantısında kabul edilen bu tasarının gerekçesi İktisat Komisyonu'nun raporuna göre, Hazine'ye gelen ve gelecek bağışların vergiden muaf tutulmasıydı. Çünkü yurda sokulacak altın, gümüş gibi kıymetli eşyalardan \%20 gümrük vergisi alınmaktaydı. Şu ana kadar doğrudan Hazine için gelen bağışlar 5383 sayılı Gümrük Kanunu'nun 17. maddesinin 2. fikrası hükmü gereğince Bakanlar Kurulu'ndan karar alınmak suretiyle vergiden muaflard1. Ancak hakiki ve hükmi şahıslar namına gelen bağışlar bu kararın dışında kalmakta ve bu bağışların yurda sokulması Maliye Bakanlığı müsaadesine bağlıydı. Bu tasarının amacı, Hazine’ye yapılan yardımın kolaylaşması ve ülkeye girecek altın ve gümüş gibi millî servetin arttırılmasıydı. $\mathrm{Bu}$ amaçlar doğrultusunda sunulan tasarı, meclis tarafından kabul edilerek kanunlaştırıldı.

12 Ekim 1960 tarihinde kabul edilen 100 sayılı kanuna göre:

"MADDE 1. - Doğrudan doğruya yahut hakiki veya hükmi şahıslar tavsit [aracı] edilerek Hazineye yardım maksadıyla ve bağış yoluyla gümrüklere gelmiş ve

\footnotetext{
73 Akşam, 16 Temmuz 1960, s. 5.

74 Tercüman, 16 Temmuz 1960, s. 5.

75 Milliyet, 20 Temmuz 1960, s. 1.

${ }^{76}$ Milliyet, 19 Temmuz 1960, s. 1.

${ }^{77}$ TBMM Tutanak Dergisi, T.C. MBK Genel Kurul Toplantıs1, 11. Birleşim, Cilt 1, 14.09.1960, s. 5.

${ }^{78}$ TBMM Tutanak Dergisi, T.C. MBK Genel Kurul Toplantısı, 14. Birleşim, Cilt 1, 29.09.1960, s. 20.

${ }^{79}$ TBMM Tutanak Dergisi, T.C. MBK Genel Kurul Toplantısı, 16. Birleşim, Cilt 2, 04.10.1960, s. 2.
} 
gelecek olan her türlü eşya ve kıymetler Gümrük Vergisi ile ithali esnasında alınan sair vergi, resim ve ücretlerden (Damga Resmi dâhil) muaf olduğu gibi, Türk parası kıymetini koruma kararları ile Dış Ticaret Rejiminin koyduğu takyitlere[koşullar] de tâbi değildir. Bu muafiyetin tatbik şekli ile eşya ve kıymetlerin Hazineye 'intikali usulü Maliye ve Gümrük ve Tekel Bakanlıklarınca müştereken tespit olunur.

MADDE 2. - Bu kanun yayımı tarihinde yürürlüğe girer.

MADDE 3. - Bu kanun hükümlerini Bakanlar Kurulu yürüttür." 80

Bağışların vergiden muaf olması için sunulan kanunun, Millî Birlik Komitesi üyeleri Vehbi Ersü ve Haydar Tunçkanat tarafından kanunun Alyans Kampanyası'nda olduğu gibi ülkeye altın, gümüş bağışı ve millî serveti arttırmak için tüm bağışları kapsamasına dair önerisi kanunun, sadece Hazine'ye yapılan bağışlar için hazırlanmasından dolayı reddedilmiştir. ${ }^{81}$

1961 yılında da bağışların devam edeceği anlaşılınca mevcut olan bağışların değerlendirilmesi için bilirkişi ücreti ve her çeşit masraflar için ve Hazine'de var olan kıymetli eşyalarla birlikte muhasebe kayıtlarına işlenmesi için 10.000 liralık ödenek konulmuştur. ${ }^{82} \mathrm{Bu}$ ödeneğe 1962 yılı Ocak ayında 20.000 lira eklenecektir. ${ }^{83}$

Kampanyanın başladığı andan itibaren gazetelerde kampanyaya olan olumsuz tavırlara hiç yer verilmemiştir. Sadece bir kez yukarıda bahsedildiği üzere "köylülerden zorla bağış için altın ve para alınacağına" dair çıkan haberlerden dolayı İç İşleri Bakanlığı'nın açıklamasına yer verilmiştir. Ancak kampanya gazetelerden görülen haliyle her ne kadar tüm halkın desteğinin sağlamış olarak gösterilse de bir kesim tarafından da eleştirilmekteydi. Bu anlamda "Bu yüzükleri kime veriyorsunuz?", "Bu yüzükler yarın şöyle böyle olur." gibi sözler söylenmekteydi. Kampanyadan hemen sonra ordudan ayrılan subaylar için "bal tutan parmağını yalar" gibi ifadeler kullanılıyordu. ${ }^{84}$ Zaten uzun süre bağışların istismar edildiği ve bağışlar ile ne yapıldığ 1 konusu tartışılmış ve ileride tekrar gündeme gelecektir.

Alyans Kampanyası 15 Temmuz 1960 tarihinde tahvillerin piyasaya sürülmesi ile artık sürekli gündemde yer alan bir konu olmamıştır. Ara sıra yapılan bağışlarla, çok nadir olarak gündeme gelmiştir. Çünkü artık Hazine'ye gelir sağlama aracı tahviller olmuştur. Aynı zamanda tahviller sonrasında da gündemde olan Yassıada Mahkemeleri gibi önemli olaylar da Alyans Kampanyası'nın gündemden düşmesine neden olmuştur.

1961 yılı için gazetelerde Kıbrıslı Türklerin yaptığı bağış ile tekrar gündeme gelen kampanyanın ${ }^{85}$ bundan sonraki gündeme gelişi ise 28 Haziran 1962 tarihinde A.P. Maraş Senatörü Nedim Evliya'nın altınların durumunu Cumhuriyet Senatosuna verdiği 6 soruluk sözlü soru önergesi ile olacaktır. Nedim Evliya'nın sözlü soru önergesi 2

\footnotetext{
${ }^{80}$ TBMM Tutanak Dergisi, T.C. MBK Genel Kurul Toplantıs1, 22. Birleşim, Cilt 2, 12.10.1960, s. 6, 7, İktisat Komisyonu Raporu No: 1/99 K. No: 69.

${ }^{81}$ TBMM Tutanak Dergisi, T.C. MBK Genel Kurul Toplantıs1, 22. Birleşim, Cilt 2, 12.10.1960, s.7; 10630 say1lı Resmî Gazete, s. 2354.

${ }^{82}$ T.C. Kurucu Meclis Tutanak Dergisi, 2. Birleşim, Cilt 2, 20.2.1961, s. 69.

${ }^{83}$ T.C. Cumhuriyet Senatosu Tutanak Dergisi, 24. Birleşim, Cilt 1, 23.1.1962, s. 6.

${ }^{84}$ T.C. Temsilciler Meclisi Tutanak Dergisi, 20. Birleşim, 23.2.1961, s. 329, 330.

${ }^{85}$ Milliyet, 18 Mart 1961, s.5.
} 
Temmuz 1962 tarihinde Maliye Bakanlığı'na gönderilmiştir. ${ }^{86}$ Evliya'nın 4 Eylül 1962 tarihinde Maliye Bakanı Ferit Melen'den aldığ 1 cevaplar şu şekildedir:

“1. Kaç kişi, kaç parça bağışta bulunmuştur ve bunların toplam miktarı nedir?

Hazine’ye nakit olarak gelen bağışlar kaza mal sandıklarıyla askeri ve mülki saymanlıkları tarafından direkt çeşitli gelir olarak ilgili yıl bütçelerine kaydedilmiştir.

Alyans, yüzük, bilezik gibi çeşitli kıymetli eşyalar İstanbul hariç ilgili saymanlıklar tarafından doğruca Hazine'ye gönderilmiştir. Buradan da Hazinec tarafından yapılan değerlendirmeden sonra Darphane ve Damga Matbaasına gönderilmişlerdir.

Bazı bağışlar mahalli komisyonlar tarafından kıymet takdiri yapılarak gönderilmiştir. Gönderilmeyen kısım içinde bakanlığın yetkili memurları ve bilirkişilerden bir komisyon oluşturularak değerlendirilip, kayıt edilmiştir. İstanbul vilayet ve kaza malsandıklarının kabul ettiği bağışlar ise doğrudan Darphaneye teslim edilmiştir. Mayıstan bu yana toplam bağış 11.171 .164 lira 15 kuruş ve 1.451 kilo 356 gram 990 santigrat muhtelif altın, gümüş, sikke ve ziynet eşyası ve 20.060.627 lira 98 kuruş nakdi yardım yapılmıştır. Bu bağışlar 233.694 şahıs veya kurum tarafından yapılmıştır. İstanbul'un bağışlarını direkt Hazine'ye gönderdiği 22.437 şahıs ve kurum bulunmaktadır. Bazı şahıs ve müesseselerin toplu olarak bağış yapması dolayısıyla tam miktarı tespit etmek mümkün değildir.

2. Bu bağışların Türk parası olarak toplam değeri nedir?

Bağışların toplam bedeli 31.231.792 lira 13 kuruştur.

3. Hali hazırda bu bağışlar nerede ve ne şekilde muhafaza edilmektedir?

'Mücevherat, kıymetli altın ve meskûk (Cumhuriyet altını) altınların bir kısmı hâlâ İstanbul Darphane ve Damga Matbası'nda' belirlenen esaslara göre muhafaza edilmektedir. Ancak meskûk altınların bir kısmı Hazine hesabına geçirilmesi için Merkez Bankası'na gönderilmiş burada muhafaza edilmektedir. ${ }^{87}$

4. Altın, gümüş ve diğer kıymetli eşyalar nakde çevrildi mi? Çevrildiyse de ne şekil ve surette çevrilmiştir?

Altın, gümüş ve diğer kıymetli eşyalar henüz nakde çevrilmemiştir. ' $\mathrm{Bu}$ kıymetlerin tasnifine Darphane ve Damga Matbaası tarafindan devam edilmektedir. Tasnifi müteakip altınlar külçe haline getirilerek Hazine'nin altın hesabına geçirilmek üzere Merkez Bankasına teslim edilecek. Taşlı ve kıymetli ziynet eşyası, usulüne uygun bir şekilde satılarak nakde çevrilecek, bilirkişi tetkikatına müteakip tarihî kıymetine haiz olduğu anlaşılanlar da, müzelere devredilecektir. Gümüş vesair madenlerden mamul olup piyasada kıymeti mevcut olmayan veya tarihî kıymeti haiz bulunmayan eşya ise, iptidai madde olarak kullanılmak üzere darphanece eritilecektir.'

5. Bilhassa Hâmit, Reşat altını, beşibiryerde ve benzeri paralar aynı haliyle muhafaza edilmekte midir? Yoksa diğerleri gibi darphanede külçe haline mi

\footnotetext{
${ }^{86}$ Milliyet, 29 Haziran 1962, s.7; TBMM Cumhuriyet Senatosu Tutanak Dergisi,75. Birleşim, Cilt 4, 02.07.1962, s.340.

${ }^{87}$ Burada yer alan Meskûk altın, darphane tarafından basılan Cumhuriyet altınının 2 türünden biridir. Diğer türü ise ziynettir. (https://www.darphane.gov.tr/kucuk-sozluk, (E.T. 28.06.2020.)
} 
getirilmiştir? Külçe haline getirilmişse bunun sebepleriyle Hazine'nin kâr ve zararı ne olmuştur?

"Reşat altından gayrı meskûk altınlardan kulpsuz olanlar yukarda da açıkladığım üzere Merkez Bankasına teslim edilmiştir. Reşat altınlar ve diğer kulplu altınlar teknik sebeplerle, Merkez Bankasınca kabul edilmediğinden (sahteleri çıktığı için) Darphaneye teslim edilmiş ve bu müessesece aynen muhafaza edilmektedir."

6. Altın, platin ve taşlı alyansların bir kısmı nikel ve benzeri madenlerden mamul alyanslarla tebdil edildiğine göre Hazine tarafindan ne miktar alyans imal ettirilmiş ne kadar sarf olunmuş ve bunlara kaç para ödenmiştir?"

"Hazine'ye bağışta bulunan vatandaşlara, verilmek üzere Darphanece 657.044 adet hâtıra alyansı imal edilmiş ve bunun 537.034 adedi vatandaşlara dağıttılmak suretiyle sarf edilmiştir. İmal edilen hâtıra alyansları için Hazine tarafından Darphaneye 30000 TL ödenmiştir" 88

Melen'in bu cevabına Evliya'nın dikkat çektiği noktalar; bağışların halen kullanılmamış olması ile kampanyanın başında hakkaniyetli davranılmayıp hükmi ve hakiki şahısların (şahıs ve kurumların) kayıtlarının detaylıca tutulmaması dolayısıyla bağış miktarı hakkında şüphe doğmasıydı. Aynı zamanda Evliya, bağışların Hazine ve Merkez Bankasında muhafaza edilmesi üzerine Melen'e Maliye Bakanlığı tarafından bunların eritilmesi için emir verilip verilmediğini sormuş ve elinde buna dair kanıtlar olduğunu ileri sürmüştür. Çünkü Hazine'nin nakdini külçe halinde muhafaza ettiğini dolayısıyla altınların eritilmesi gerektiğini söyleyen Evliya, Reşat ve Hamit altınlarının piyasada bulunmamasına rağmen eritilmesinin hesapsızlık olduğunu ve Melen'in ikinci bir emirle bu duruma engel olması gerektiğini söylemiştir. Sadece Reşat ve Hamit altınları değil Aziz, Atatürk ve Cumhuriyet altınlarının maden kıymetleri ile piyasadaki kıymetleri arasında ciddi farklar olduğunu da ve iki seneden beri tasnif edilemediği ifade edilen bu altınların eritilmesinden ziyade altınları resmî borsalarda satılıp gelen paralar ile Hazine'ye külçe satın almanın Hazine menfaatine olduğunu söylemiştir. Bu konuşmada dikkat çeken başka bir husus da Evliya'nın da değindiği gibi ${ }^{89}$ kampanyaya ait resmî kayıtların çok az veya hiç olmamasıdır. Kampanya Evliya'nın soru önergesine kadar sadece ödenek ve bazı gündem konuları dahilinde meclis tutanaklarında yer almıştır.

${ }^{88}$ TBMM Cumhuriyet Senatosu Tutanak Dergisi,75. Birleşim, Cilt 4, 02.07.1962, s.340; TBMM Cumhuriyet Senatosu Tutanak Dergisi, 79. Birleşim, Cilt 4, 04.09.1962, s.496-498.

89 Devlet arşivleri, resmî gazete ve meclis tutanakları bazında yapılan araştırma boyunca kampanyanın başlangıç ve gidişatına dair resmî bir evrak bulunamamıştır. Bulunan evraklar kampanyanın bahsinin geçtiği meclis tutanakları, vergi muafiyeti kanunu ve Gürsel'in açıklamasının yer aldığı Resmî Gazete'dir. Bunlara da çalışma içinde yer verilmiştir. Kampanyadan 2 yıl sonra Nedim Evliya'nın soru önergesi üzerine Maliye Bakanı Ferit Melen'in cevaplarının yer aldığı tutanak kampanya hakkındaki detaylı tek resmi evraktır. Bunun dışında resmi olarak kampanyanın başlaması ve sürecine dair bir evrak bulunmamaktadır. Evliya'da Melen'e Maliye Bakanlığının Senato'ya sunulan beyanlarını 4 aydır taramasına rağmen 1960,1961 ve 1962 bütçelerinde herhangi bir kayıt bulamadığını söylemektedir. 
Kampanyanın kayıtlanması adına tek sorunun bu olmadığını, toplu bağışlarda tek bir makbuz verildiğini ve bazı vatandaşların bu yüzden bağışta bulunduğu halde bir makbuz, bir evraka sahip olmadığını da dile getirmiştir. Aynı zamanda Evliya, İstanbul'daki bağışların direkt darphaneye gönderilirken diğer bağışların şehirler arasında gidip gelmesine anlam verememiş ve bu kadar yüksek katılıma ve Kıbrıs'ın da büyük bağışlarda bulunmasına rağmen söylenen miktarın bu denli az olmasının Bakanın verilerinin gerçek olmadığını ortaya koyduğunu söylemekteydi.

Evliya'nın bundan sonra değindiği konu ise daha önce de bahsedildiği üzere bağışların istismar edildiği, nasıl kullanıldığı gibi ifadeleri desteklemekte ve basının bunlara hiç yer vermeyerek yanlı bir politika izlediğini ortaya koymaktadır. Evliya vatandaşların süreci bilmediği ve bağışların "toplayanlar tarafından bir anda nakde çevrilip bu paralarla da apartman, han inşa edildiğini”-e- dair ithamlar olduğunu ifade etmekte ve bu yüzden halk tarafından bu evlere "alyans, yüzük, küpe apartmanı" diye isimler takıldığını söylemekteydi. Ayrıca bir vatandaşın yaptığı bağıştan kıymetli bir taşın Hilton salonlarında, vapurda birinin parmağında görüldüğünü, sahibiyle yüzüğü takan kişi arasında münakaşalar olduğu şeklinde de ithamlar olduğunu söylemekteydi. $\mathrm{Bu}$ ithamların herkes tarafından duyulduğunu ve bunların çözülmek zorunda olduğunu söylemektedir. Evliya'nın bu ithamlarına karşı daha önce de bu konularda sergilenen tavır gibi Melen de bunları söylenti ve dedikodu olarak nitelendirmiştir. Ancak bu konu uzun yıllar Türk tarihinde tartışılan konulardan olmuştur. ${ }^{90} \mathrm{Bu}$ konuda Ankara Yücetepe' deki konutlar “Alyans Evler" olarak nitelendirilirken ${ }^{91}$ bir kısım bu konutların ailelerinin uzun yıllar para ödeyerek aldığını ifade etmiştir. ${ }^{92}$

Melen toplu bağışlar dolayısıyla kişi sayısının kesin olmadığını, tasnif bitince altınların eritileceğini, aslında tasnifin bittiğini ama kıymet takdirinin uzun sürdüğünü söylemiştir. Herhangi bir kayıt bulunmamasına dair ise: Bağışların bütçede görülmediğini, bağış kısmına yıl içinde ne kadar bağış yapılacağı bilinmediği için sıfır konulduğunu, asıl miktarların hesabı katilerde görüldüğünü söylemiştir. ${ }^{93}$ Evliya'nın bağışların gazetelerde yer alan haberlere göre az olduğunu söylemesi üzerine ise kampanyanın bağışa dayalı olduğunu zorunlu olmadığını bu yüzden maddiyatından çok maneviyat olarak kıymeti olduğunu söylemiştir. ${ }^{94}$

Nedim Evliya'nın soru önergesinden sadece üç gün sonra Hazine'deki bağışların tasnifi hakkında gazetelerde çıkan haber aslında basının halka yönelik bir araç olarak kullanıldığını gözler önüne sermekteydi. Haberde yapılan açıklamalara göre: tüm ziynet eşyaları bilezik, yüzük, küpe, alyans olarak özelliklerine göre, altınlar Hamit, Cumhuriyet, Gülden, Reşat, Beşibiryerde, Gümüş ve Platinleri de ayarlarına göre tasnif edilmektedir. (EK 11) Tasnif bu yıl (1962) sonunda tamamlanacak, ziynet eşyaları

\footnotetext{
${ }^{90}$ TBMM Cumhuriyet Senatosu Tutanak Dergisi, 79. Birleşim, Cilt 4, 04.09.1962, s.498-502.)

${ }^{91}$ Aslandaş, Bıçakçı, 1995; 28.

${ }^{92}$ https://www.hurriyet.com.tr/alyans-degil-alinteri-23211241 (E. T. : 28.06.2020)

${ }_{93}$ Hesabı katilere, tutanakların o k1smının internet ortamına aktarılmamas1 ve makalenin mevcut pandemi şartlarında yazılmasından dolayı ulaşılamadığı için incelenememiştir. TBMM Kurucu Meclisi Tutanak Dergisi, 26. Birleşim, Cilt 2, 04.09.1961.

${ }^{94}$ TBMM Cumhuriyet Senatosu Tutanak Dergisi, 79. Birleşim, Cilt 4, 04.09.1962, s.501-503.
} 
darphanenin soğuk mahzeninde muhafaza edilecektir. Tasnif bitiminde eritilip Merkez Bankası Hazine hesabına yatırılacaktır. Muhafaza edilen bağış miktarı 1416 kilo 554 gram 981 mg'dır. Para olarak değeri ise 10 milyon 828 bindi. $^{95}$

\section{Sonuç}

27 Mayıs 1960 Askerî Darbesi sonrası MBK tarafından darbeyi halka benimsetme, yumuşatma çalışmaları ve gelir sağlamak için başlatılan kampanyalar silsilesinin ilki Alyans Kampanyası olmuştur. Bu anlamda basının kiminin taraflı kiminin baskı nedeniyle mecburi politikası ile darbe halka benimsetilmeye ihtilal ve inkılap olarak kabul ettirilmeye, kampanyalara katılımı artırmak ve darbenin ekonomik duruma iyi geldiğinin halka kabul ettirilmesi amaçlı çalışılmıştır. Ancak D. P.'nin son döneminde izlerini gösteren ekonomik kriz darbe sonrası devam etmiş, uzun süre siyasi istikrarın sağlanamaması ile giderek artmıştır. Bu dönem ülkenin durumu hakkında aşırı iyimser politika ile haber yapan gazeteler daha sonra darbenin üzerinden zaman geçmesi ve ordunun baskısının azalması ile yavaş yavaş haberlerinde aleyhte konulara yer vereceklerdir. Her ne kadar o dönem basın tarafindan yer verilmese de kampanya hakkında olumlu olduğu kadar olumsuz bir kesim bulunmaktadır. $\mathrm{Bu}$ süreçte kampanyanın başlangıcına dair resmî bir evrak bulunmamasının yanında ne zaman son bulduğuna dair resmî bir belgeye veya habere de rastlanmamıştır. Kampanya hakkında tek detaylı evrakı Nedim Evliya'nın soru önergesine Maliye Bakanlığı tarafindan verilen cevapların yer aldığı evraktır.

Resmî makamların Melen'in açıklamasında olduğu gibi bağışların makbuzlarla kabul edilmesine rağmen kesin bilgi vermemesi, bağışların teslim edildiği kurumların sıkı bir denetime tabi tutulmaması ve halkın yüzüklerinin subay eşleri tarafindan kullanıldığı gibi pek çok iddia, çeşitli evrakların olmaması, Hazine'nin durumunun çok kötü olduğu zaman boyunca bağışların kullanılmaması ve 1962'ye kadar tasnif bile edilmemiş olması bu kampanyanın hep bir soru işareti ile kalmasına neden olmuştur.

İlgililerin nüfusun üçte birinin evli olması ve yapılacak bağışların 200 milyonu bulmasını beklediği süreçten sonra toplam kampanya bağışlarının 31 milyon olması cidden beklenenin çok altında bir tutardır. Sadece bazı vatandaşlar tarafından milyonlar ve kilolarca altın bağışlanmıştır. Bağışların yarışa dönüştüğünü ve büyük katılımlar sağlandığ1 söylenildikten sonra oldukça düşük olan bu miktarın açıklanması herkesi şüphe içinde bırakmıştır.Kampanyadaki bağışların, kesin olarak nasıl kullanıldığına dair resmî bir evrak bulunmaması hem kampanya boyunca hem de kampanyadan sonra bağışlara ne olduğu, nasıl kullanıldığı hakkında yıllarca süren tartışmalara neden olacaktır.

\footnotetext{
${ }^{95}$ Milliyet, 5 Temmuz 1962, s. 1.
} 


\section{KAYNAKLAR}

\section{Meclis Tutanakları}

TBMM Tutanak Dergisi, T.C. MBK Genel Kurul Toplantıs1, 11. Birleşim, Cilt 1, 14.09.1960.

TBMM Tutanak Dergisi, T.C. MBK Genel Kurul Toplantısı, 14. Birleşim, Cilt 1, 29.09.1960.

TBMM Tutanak Dergisi, T.C. MBK Genel Kurul Toplantıs1, 16. Birleşim, Cilt 2, 04.10.1960.

TBMM Tutanak Dergisi, T.C. MBK Genel Kurul Toplantıs1, 22. Birleşim, Cilt 2, 12.10.1960, İktisat Komisyonu Raporu No: 1/99 K. No: 69.

T.C. Kurucu Meclis Tutanak Dergisi, 2. Birleşim, Cilt 2, 20.2.1961.

T.C. Temsilciler Meclisi Tutanak Dergisi, 20. Birleşim, 23.2.1961.

T.C. Cumhuriyet Senatosu Tutanak Dergisi, 24. Birleşim, Cilt 1, 23.1.1962.

TBMM Cumhuriyet Senatosu Tutanak Dergisi,75. Birleşim, Cilt 4, 02.07.1962.

TBMM Cumhuriyet Senatosu Tutanak Dergisi, 79. Birleşim, Cilt 4, 04.09.1962.

\section{Gazeteler}

Akşam
Demokrat İmir
Ekonomi Gazetesi
Milliyet
Resmî Gazete
Tercüman
Ulus
Yeni Sabah

3.Telif ve Tetkik Eserler

Alkan 2016 Mehmet Öznur Alkan, "27 Mayıs’tan Propaganda Hatıraları” Atlas Tarih ,No: 41, s.124-129.

Aslandaşve Bıçakçı 1995 Alper Sedat Aslandaş - Baskın Bıçakçı, Popüler Siyasi Deyimler Sözlüğü, İletişimYayınları İstanbul

Demir 2018 Özkan Demir, "Türk Siyasal Hayatı, Osmanlı Modernleşmesinden Günümüze”, Hasan Acar (Ed.), Türkiye'nin Ekonomik Politikasına Etkisi: Planlı Kalknnma Dönemi’ne Geçiş, Nobel Yayıncilık Ankara, s.435-462.

Soysal 1964 İlhami Soysal, "Bir Türk Şairinin ölümü”, Yön Dergisi 3(86), 8-9. Erişim Adresi: Marmara Üniversitesi Açık Erișim Sistemi

Tok 2017 Eyüp Tok, Türkiye Ekonomisinin Liberalleşme Süreci (19231990) (Doktora tezi, T. C. Dumlupınar Üniversitesi, Kütahya). 
Tuna 2017

TÜİK 2010

Yavuz 2017

Yücel 2017

Weiker 1967
Iş11 Tuna, “27 Mayıs 1960 Darbesi'nin Edirne'deki Yansımaları ve DP Edirne Milletvekillerinin İfadeleri’, Yakın Dönem Türkiye Araştırmaları Dergisi, 16(32), s.65-85.

TÜİK , Istatistik Göstergeler (1923-2009)Ankara.

ErdemYavuz,"1960 Darbesi Sonrası Basında Alg1 Yönetimi ve Propaganda (Cumhuriyet-Hürriyet-Milliyet Gazeteleri Örneği)", Akademik Sosyal Araştırmalar Dergisi 9(63), s. 95119 DOI:https://doi.org/10.16992/ASOS.13228

Hüseyin Yücel, Cumhuriyet Ekonomisinin Kuruluşu ve Gelişimi, Türkiye Barolar Birliği Yayınları Ankara.

Walter F. Weiker, 1960 Türk Ihtilali, (Çev.Mete Ergin) Cem Yayınevi, İstanbul.

\section{Internet Kaynakları}

http://www.cukurovaexpres.com/27-mayis-ve-mersin-6-makale,344.html (E.T. 27.06.2020)

https://www.darphane.gov.tr/kucuk-sozluk (E.T. 28.06.2020)

https://www.hurriyet.com.tr/alyans-degil-alinteri-23211241 (E.T. 28.06.2020)

https://www.sabah.com.tr/galeri/turkiye/gorsellerle-27-mayis-1960-darbesi-

$\underline{1545045872 / 134}$ (E.T. : 24.06.2020)

\section{SUMMARY}

There was a period of major economic developments in Turkey during the 19501954 period of the Democrat Party government. However, the second period until 19541960 would be a period when the economic decline started compared to the first period. In this period, the positive atmosphere of the first years was replaced by a great absence, economic and financial crisis, with the problems such as the increasing foreign trade deficit, foreign debt, unemployment, decrease in purchasing power and the depletion of gold, foreign exchange reserves and the decline of economic growth during the Second World War. The military coup took place on May 27, 1960, citing economic problems of this kind as well as political crises as important reasons. The administration passed from the Democratic Party to the National Unity Committee. The problems experienced during the Democratic Party period would be frequently mentioned by the National Unity Committee, which was in power after the 1960 coup, and the Democratic Party's economic policy would be criticized on the basis of issues such as lack of planning and waste. As before the coup, economic conditions and problems would frequently take place in the society during the period of the National Unity Committee. At that time, the National Unity Committee would seek help from the public for the economic crisis, which it claimed was the result of the economic policies of the Democratic Party period. These campaigns were to be carried out through bonds. One of the campaigns launched for these purposes was the Wedding Ring Campaign. This campaign, initiated by the 1st Armored Brigade, attracted great attention from the 
public in a short time. The campaign was initiated with the aim of increasing the gold stock and generating income for the treasury. This campaign is of great importance in terms of reflecting the post-1960 economic situation.

Citizens were handing engagement rings and various items to the commissions. This campaign was supported not only among our own citizens, but also from many different religious members, churches, Armenian schools and citizens of foreign origin. Immediately two days after the campaign started, all branches of the Ministry of Finance started collecting these donations in return for a receipt. Of course, in this process, some institutions and citizens have also handed their jewels to the Treasury General Directorate to transfer them to the state treasury.

In all newspapers, donations of the Wedding Ring Campaign were frequently included every day and predictions were made about the contribution to the treasury. The newspapers contained news aimed at increasing participation in the campaign, and the names of the donors and the amount of donations were daily in the newspapers to increase donations.

Citizens who had negative events and negative thoughts about the campaign were not included in the newspapers. For this campaign, besides small donations, huge donations were also made. For the donor of the rings, it was decided to give souvenir rings to the citizens. The purpose of this practice was to prevent people who donated their rings from buying new rings and to prevent gold prices from rising. In addition to the Wedding Ring Campaign, it was launched by the tradesmen in the Discount Campaign to alleviate the current economic crisis conditions.

Another important issue during the campaign period was the law regarding exemption from the tax, which was accepted as a result of the Economic Commission Report, to the treasury.

The Wedding Ring Campaign, which remained on the agenda for days, fell off the agenda due to the fact that some important events such as the Yassiada Courts occupied the agenda and the sale of Hürriyet Bonds, another way of generating revenue for the treasury. In the next period, there is no information about the exact end date of the Wedding Ring Campaign, which is mentioned in the parliament with appropriations and some agenda topics.

The first detailed official document about the campaign is the report containing the response of the Ministry of Finance to Nedim Evliya's six-question proposal in the study. Information included in the minutes: how many people, how many donations and total amount: Total value in Turkish currency, where and how donations are kept: whether gold, silver and other valuable items are converted into cash: If it has been translated, in what form and form it has been translated: whether Hamit, Reşat gold, fiveibiry and similar coins are kept in the same condition, especially due to the expense in the production phase: or whether it was turned into bullion in the mint like others, and therefore the profit and loss of the treasury; how many souvenir wedding rings are produced by the treasury; how much was spent and how much money was paid for them. In addition to these questions in the minutes, issues such as what the donations are used for, donations made without receipts, negative statements about the campaign, 
the biased policy of the press and the absence of these issues in the press are also discussed.

As Evliya mentioned in the parliamentary meeting, this campaign has always remained a question mark because as with the Melen statement of the official authorities, donations were accepted with receipts with no precise informatio, the institutions to which the donations were delivered were not subject to strict supervision, and there have been allegations that the rings of the people were used by the wives of the officers, there were no documents, donations were not used during the time when the treasury was in dire condition, and it was not even classified until 1962. The absence of official documentation on how the donations in the campaign are used will cause years of debate about what happened to the donations and how they were used, both during and after the campaign. 


\section{EKLER}

EK 1: Alyanslarını bağıșlayan bir çift. Akșam, 12 Haziran 1960, s. 3.

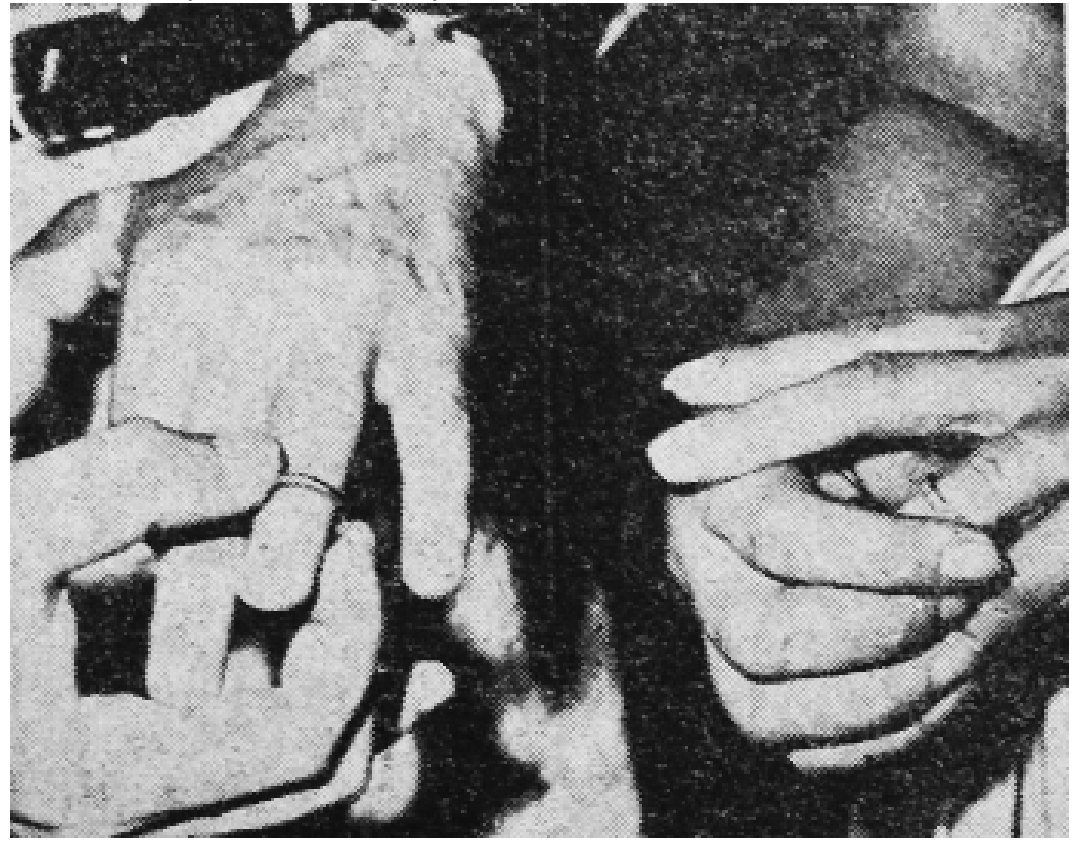

EK 2. Millî Emlak Müdürlüğünde altın bağışlarını teslim alan komisyon. Akşam, 12 Haziran 1960, s. 4.

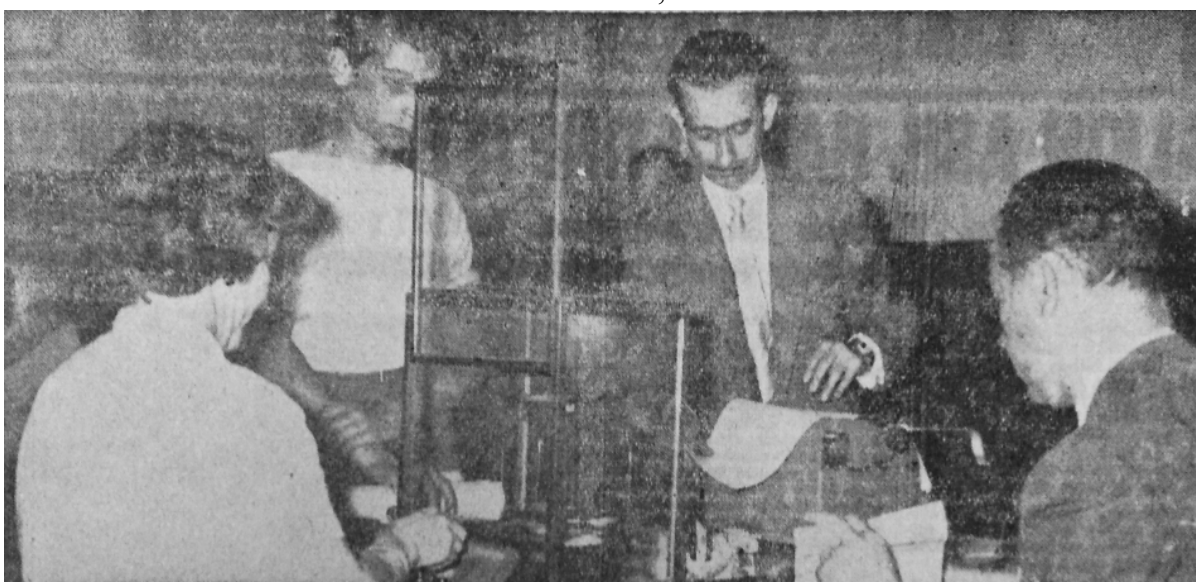


EK 3. Bağıșları teslim alan heyetler. Milliyet, 29 Haziran 1960, s. 1.
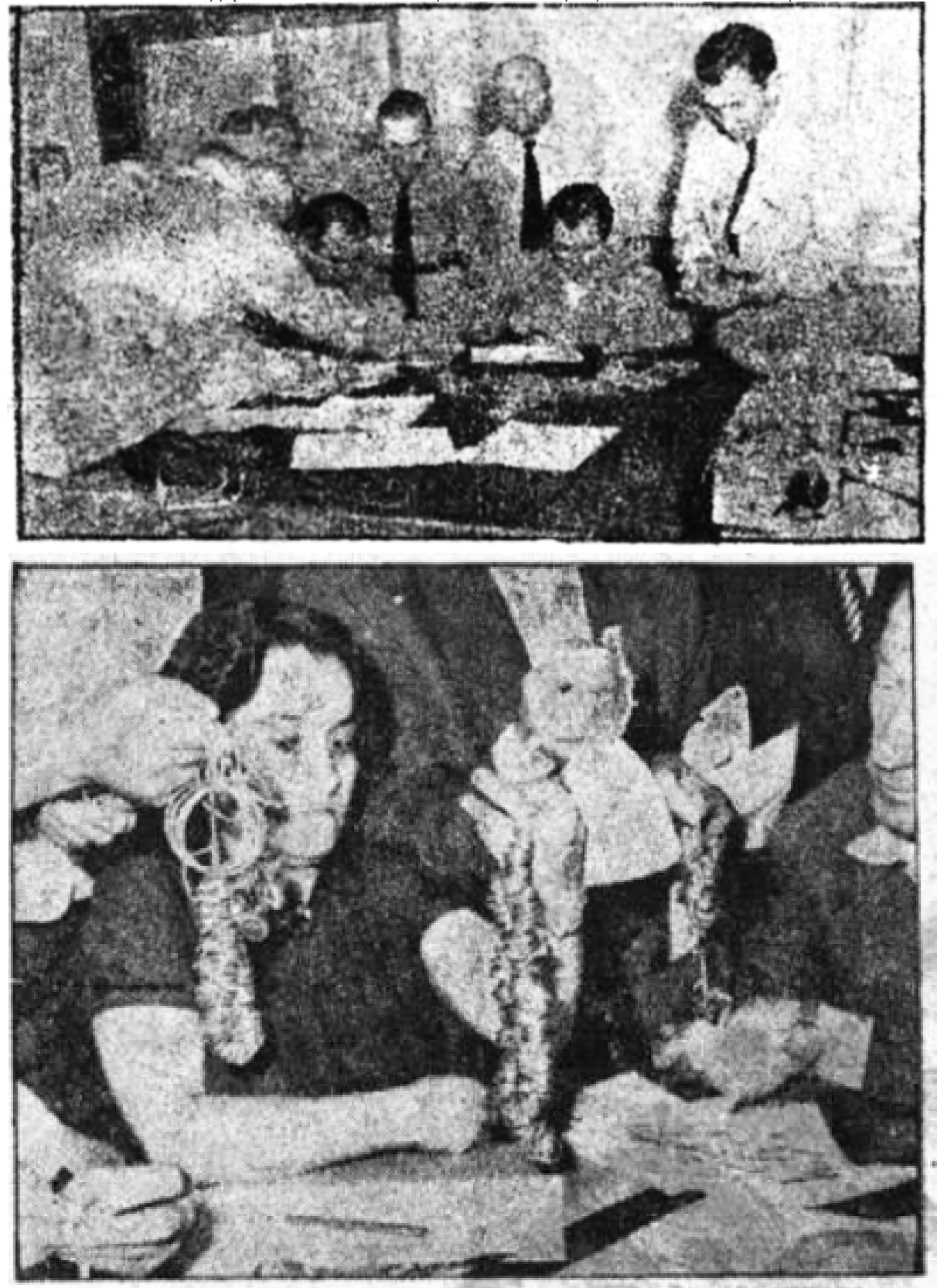
EK 4. Cemal Gürsel'in 16 Haziran 1960 tarihli tebliğde yer alan konuşmasının tam metni.

Hazinenin açığını kapatmak için ordu mensuplarının' önderlik ettikleri ve hemen sivil vatandaşlarımız tarafından takip edilen hazineye bağış kampanyasını heyecan ve iftiharla takip ediyorum. Bir ordu mensubu sıfatiyle maddi durumlarını yakından bildiğim subay arkadaşlarımın ve ailelerinin milletimizin içinde bulunduğu bu müstesna günlerde seve seve yaptıkları bağışların ifade ettiği büyük manevi kıymeti herkesten daha iyi anlıyor ve heyecan duyuyorum. Kendilerine bütün kalbimle teşekkür ederim. Subay arkadaşlarıma hemen iltihak eden sivil halkımızın ve muhtelif meslek teşekküllerinin vatanperverlik duygularını tebcil ederim. Bu hareketin büyük bir milli tesanüt nişanesi olduğundan hiç şüphe edilemez. Ancak hazinenin ihtiyacı olan parayı karşılıksız bağışlar yolu ile teminden ziyade (Hürriyet istikrazı) adını taşıyacak olan iç istikraz tahvilleri ile sağlamak kararındayız. Bu suretle, karşılıksız yardımlar yerine hükümetin sizlere borçlanması suretiyle yapacağınız yardımları tercih ettik. $\mathrm{Bu}$ tahvillerin kısa bir zaman içinde şartları ve satış tarihi ilân edilecektir. Vatandaşlarımın buna da büyük bir tehalükle katılacaklarını ümit ederek hepinizi sevgi ve saygı ile selâmlarım.

EK 5. Farklı bağışlardan gazeteye yansıyan bir görsel. (Akşam, 16 Haziran 1960, s. 3.)

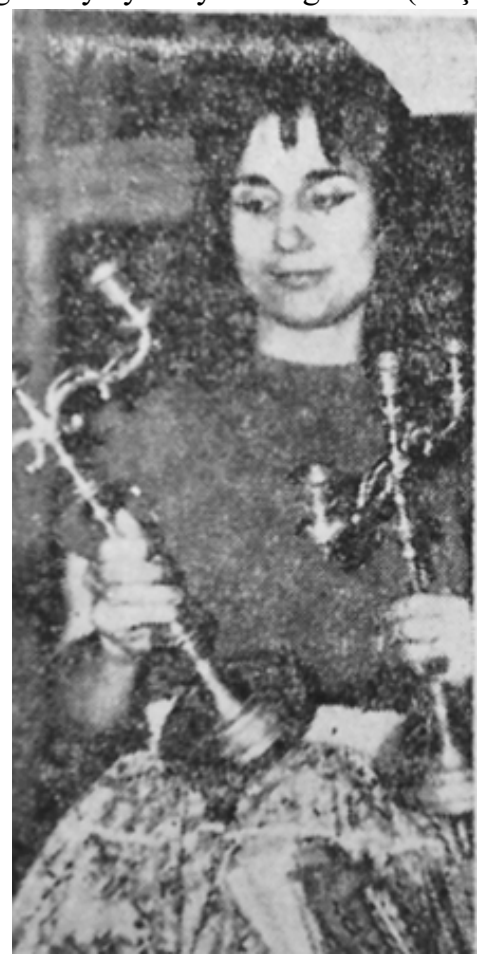




\section{İbrahim INCİ- Kübra ASLAN}

EK 6. Haham başının bağışladığı som altın kolye. Akşam, 18 Haziran 1960, s. 1.

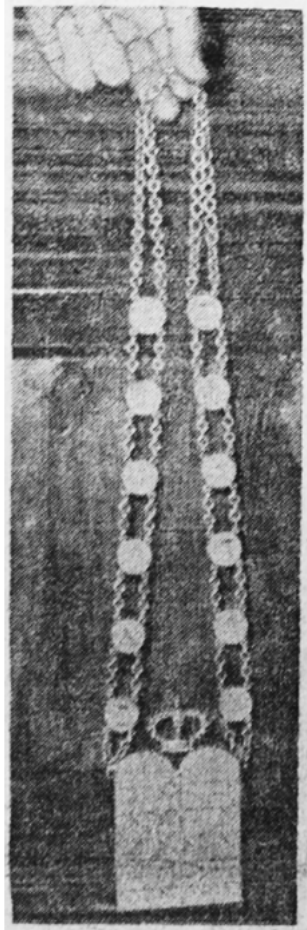

EK 7. Toplanan alyansların ölçümü yapılırken. Akșam, 5 Temmuz 1960, s. 1.

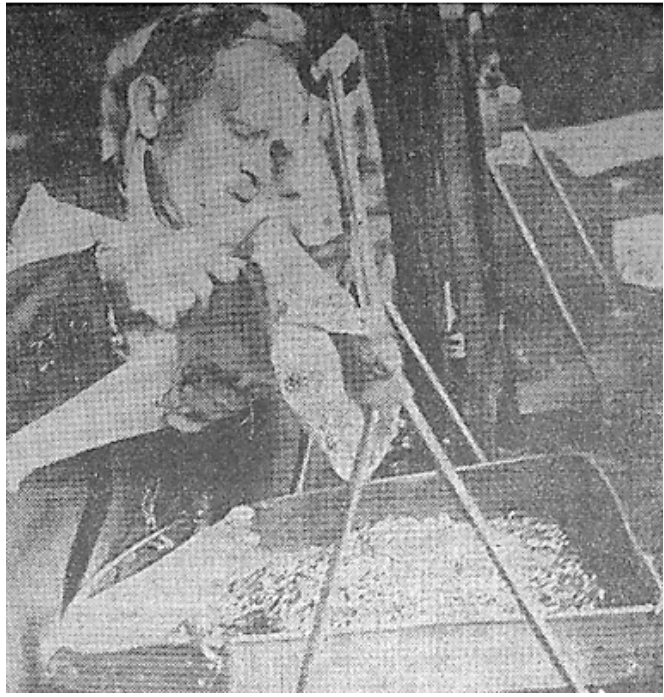


EK 8. Gazetedeki bir tahvil reklamı. Akşam, 17 Temmuz 1960, s. 3.

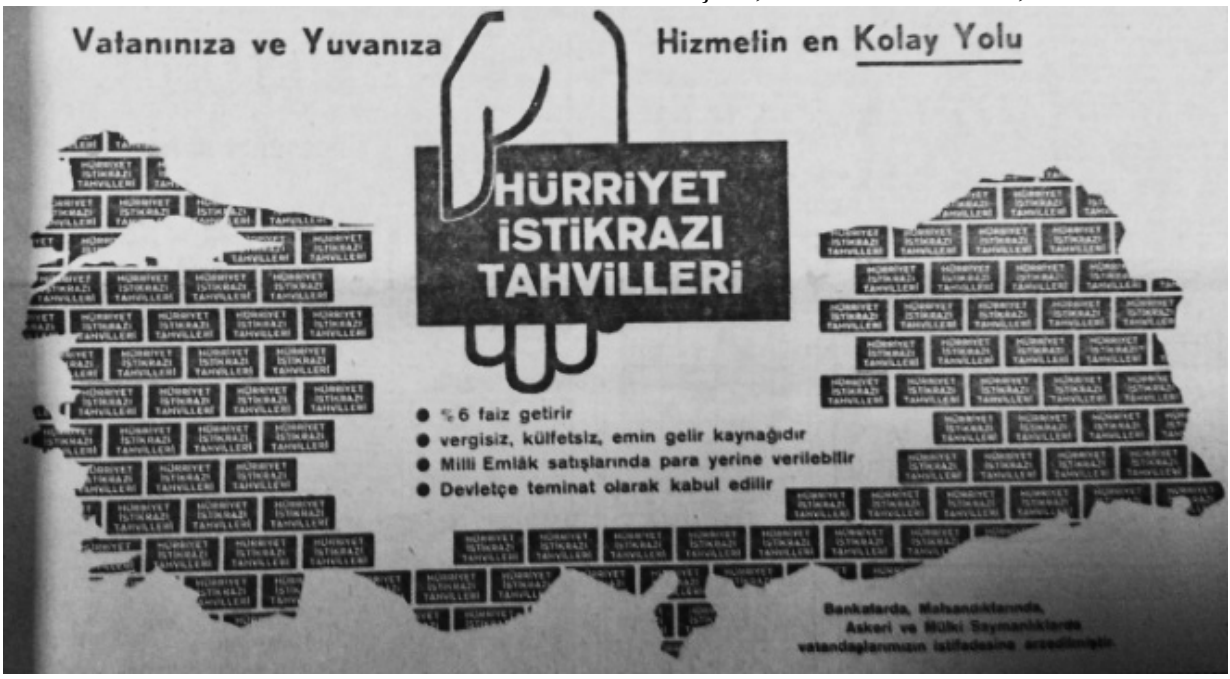

EK 9. Vatandaşa bağışları karşılığında dağıtılan hatıra

halkalar.https://www.sabah.com.tr/galeri/turkiye/gorsellerle-27-mayis-1960-darbesi1545045872/134, (E.T. : 24.06.2020)

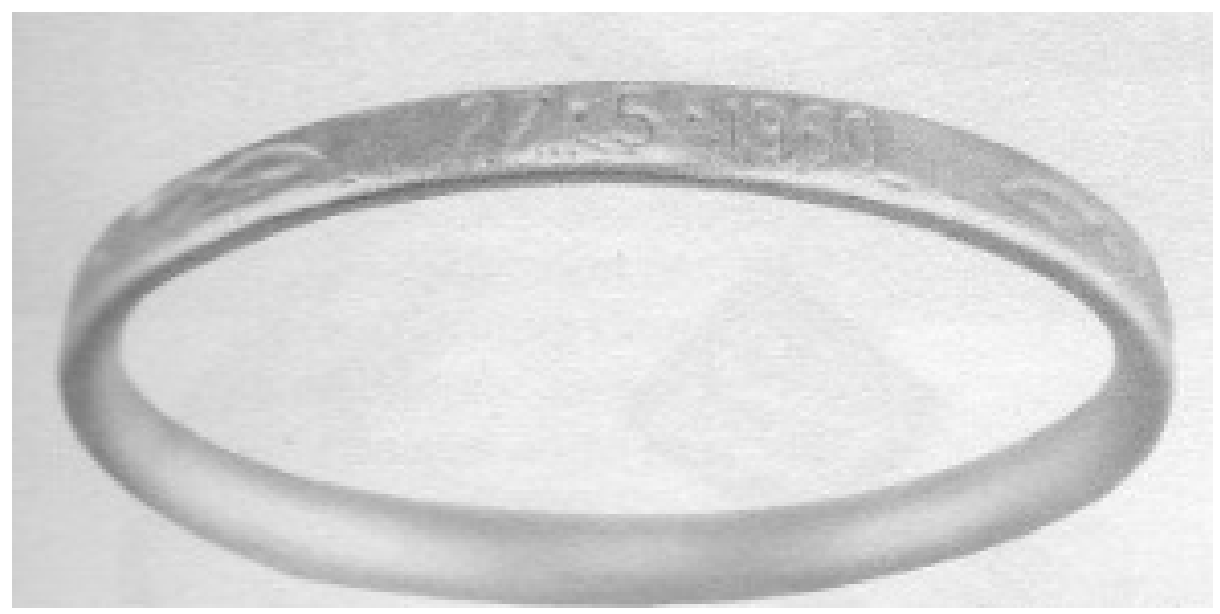




\section{İbrahim INCİ- Kübra ASLAN}

EK 10. Hatıra halkaların dağıtımı. Milliyet, 20 Temmuz 1960, s. 1.

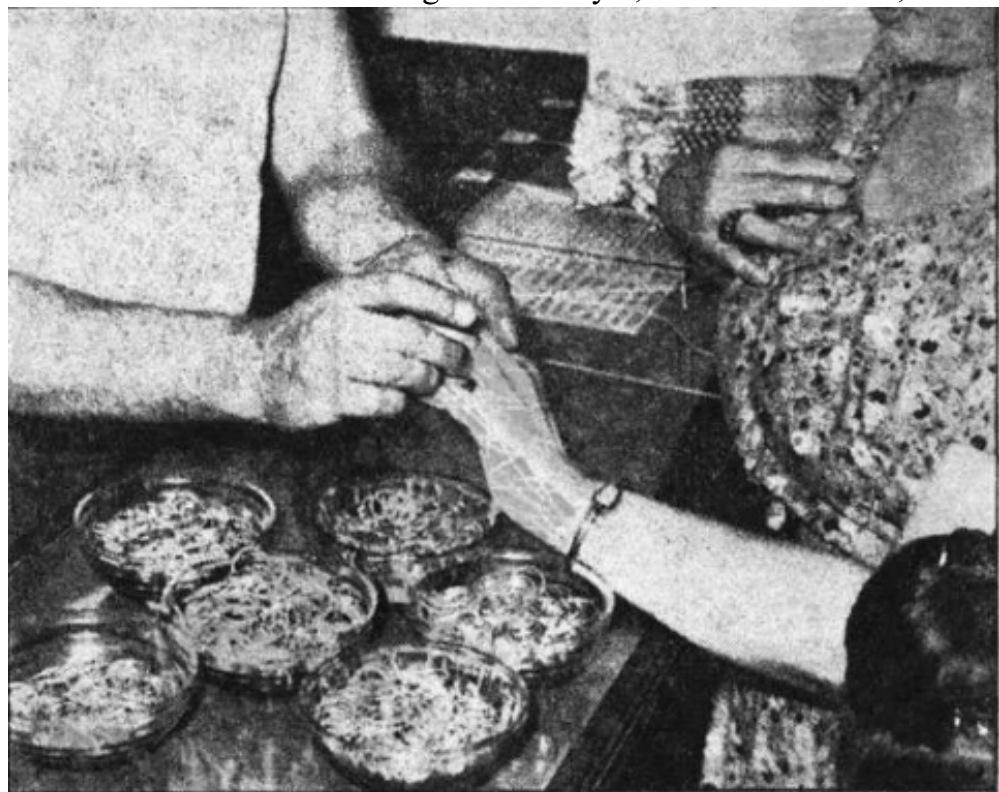

EK 11. Darphane deposundaki tasnif edilen bağışlar. Milliyet, 5 Temmuz 1962, s. 1.

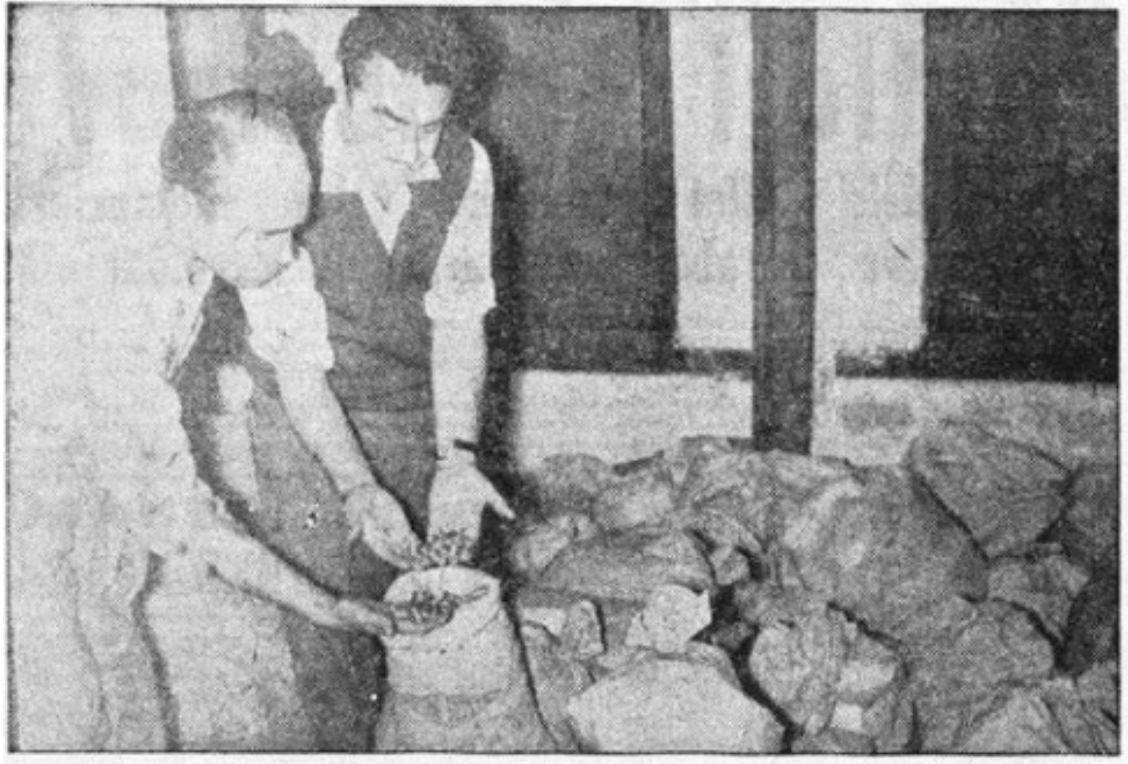

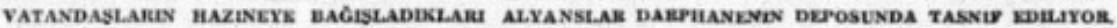

